\title{
Upaya Meningkatan Perkembangan Kognitif dengan Membilang Melalui Media Permainan Congklak pada Anak Kelompok B di PAUD Putra Pertiwi Kecamatan Lubuk Sandi Kabupaten Seluma
}

\author{
D. Y. Sari ${ }^{1)}$; R. Partikasari ${ }^{1, \text { a) }}$; M. Haryono ${ }^{1)}$ \\ Affiliation: \\ 1. Program Studi Pendidikan \\ Guru PAUD FKIP UNIVED \\ Bengkulu \\ Corresponding Author: \\ a.rkpar85@gmail.com

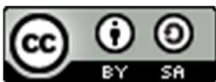 \\ Abstract \\ The purpose of this study was to determine children's cognitive development \\ through the congklak game method in PAUD Pitra Pertiwi, Lubuk Sandi District, \\ Seluma Regency. This classroom action research uses the Jhon Elliot model, \\ where each cycle consists of four stages, namely planning, implementing, \\ observing, and reflecting. The results of the research obtained show that the \\ application of playing congklak can improve the cognitive development of \\ children aged 5-6 years in PAUD Putra Pertiwi, Lubuk Sandi District, Seluma \\ Regency. This increase occurs because, at each stage of the meeting, \\ improvements are made, so that children get used to learning activities using \\ congklak media. The cognitive development of children by counting through \\ congklak media in PAUD Putra Pertiwi Seluma Regency reaches $96 \%$ with the \\ criteria developing according to expectations (BSH).
}

Keyword: Cognitive development; counting; congklak games 


\section{Pendahuluan}

Anak usia dini memiliki karakteristik yang unik, memiliki kekhasan masing-masing yang tidak sama antara anak yang satu dengan yang lain. Pendidikan memegang peranan penting pada masa ini. Hal ini disebabkan masa usia dini merupakan masa usia keemasan (golden age) yang tidak bisa diulang untuk kedua kalinya. Pendidikan anak usia dini adalahanak yang berusia 0-6 tahun, pendidikan anak usia dini memiliki peranan yang sangat penting untuk mengembangkan kepribadian anak serta mempersiapkan anak untuk memasuki jenjang pendidikan yang lebih lanjut.

Pendidikan Anak Usia Dini merupakan upaya pembinaan yang ditujukan bagi anak sejak lahir sampai dengan usia delapan tahun yang dilakukan melalui pemberian rangsangan pendidikan untuk membantu pertumbuhan dan perkembangan jasmani dan rohani agar anak memiliki kesiapan dalam memasuki pendidikan lebih lanjut (Partini, 2010: 33).

Dalam Undang-undang Republik Indonesia No. 20 Tahun 2003 tentang Sistem Pendidikan Nasional Bab 1, Pasal 1, Butir 14, yang menyatakan bahwa: Pendidikan Anak Usia Dini adalah suatu upaya pembinaan yang ditujukan kepada anak sejak lahir sampai dengan usia enam tahun yang dilakukan melalui pemberian rangsangan pendidikan untuk membantu pertumbuhan dan perkembangan jasmani dan rohani agar anak memiliki kesiapan dalam memasuki pendidikan lebih lanjut.

Bentuk pendekatan perkembangan yang penting adalah pendekatan perkembangan kognitif, hal ini dikarenakan asumsi dan keyakinan-keyakinan bahwa kemampuan kognitif merupakan suatu yang fundamental dan yang membimbing tingkah laku anak. Kunci untuk memahami tingkahlaku anak terletak pada pemahaman bagaimana pengetahuan tersebut terstruktur dalam berbagai aspeknya. Modelmodel perkembangan kognitif salah satunya adalah model Piaget. Piaget meyakini bahwa intelegensi bukan sesuatu yang dimiliki anak, melainkan yang dilakukan anaktersebut (Ahmad Susanto, 2011: 47).

Salah satu bentuk perkembangan kognitif adalah perkembangan kemampuan berhitung. Begitu pentingnya kemampuan berhitung bagi manusia, maka perlu diajarkan sejak dini, dengan berbagai media dan metode. Perlunya media dan metode yang tepat dalam pembelajaran berhitung karena anak sampai usia 5 tahun belum dapat melakukan kegiatan berhitung dengan sesungguhnya (berhitung dengan bilangan abstrak). Pada masa inianak berada pada tahap berhitung permulaan yaituanak berhitung dengan benda-benda dari lingkungan terdekatnya dalam situasi permainan yang menyenangkan sehingga perlu diajarkan sejak dini, dengan berbagai media dan metode yang tepat jangan sampai dapat merusak pola perkembangan anak.

Kegiatan belajar mengajar merupakan tugas rutin seorang guru dalam mengembangkan bakat dan kemampuan anak, untuk itu seorang guru dituntut agar dapat selalu mengembangkan kecakapan secara professional dalam mengelola kelas, agar bakat dan kemampuan anak dapat berkembang secara optimal. Salah satu kecakapan yang perlu dikembangkan adalah kecakapan dalam menggunakan metode pembelajaran yang tepat dan efektif, sehingga penanaman konsep tepat kepada anak. Guru juga merupakan motivator dan fasilitator dituntut untuk dapat menstimulus anak agar perkembangannya maksimal. Pemberian stimulus yang tepat pada anak tentu akan menjadi efektif apabila dapat menggunakan media pembelajaran yang tepat pula. Daryono (2013: 67), mengemukakan bahwa media pembelajaran adalah alat yang dapat membantu proses belajar mengajar yang berfungsi memperjelas makna pesan yang disampaikan sehingga tujuan pengajaran dapat disampaikan dengan lebih baik dan sempurna.

Rendahnya kemampuan membilang dikarenakan kegiatan pembelajaran kurang bervariasi dalam penggunaan media yang diterapkan oleh guru. Karena guru hanya menggunakan media yang monoton oleh karena itu anak akan merasa bosan dan jenuh selain itu perkembangan anak kurang optimal. Saat observasi awal penulis melihat guru paud saat mengajar berhitung permulaan dengan mengenal bilanga tidak menggunakan media, hanya menuliskan bilangan dipapan tulis, sehingga banyak anak yang asik bermain sendiri, mengganggu temannya. Media pembelajaran pada tingkat Paud sangat di perlukan saat belajar, karena dunia anak merupakan dunia yang penuh dengan imajinasi, maka dari itu pembelajaran yang ada di Paud seharusnya menarik dan menyenangkan. Dalam mengembangkan kemampuan membilang pada anak dapat dilakukan dengan berbagai hal, salah satunya dengan melalui suatu permainan. Bermain 
merupakan suatu kegiatan yang menyenangkan bagi anak, bermain juga membantu anak mengenal dirinya, dengan siapa ia hidup, serta lingkungan tempat ia hidup.

Melalui bermain anak memperoleh kesempatan untuk berkreasi, bereksplorasi, menemukan, dan mengekspresikan perasaannya salah satu permainan tersebut adalah dengan menerapkan permainan tradisional congklak.

Berdasarkan uraian di atas peneliti beranggapan pentingnya diadakan penelitian mengenai kemampuan membilang anak melalui Permainan tradisional congklak oleh karena itu penulis memilih judul "Upaya Meningkatan Perkembangan Kognitif Dengan Membilang Melalui Media Permainan Congklak Pada Anak Kelompok B Di PAUD Putra Pertiwi Kecamatan Lubuk Sandi Kabupaten Seluma”.

\section{Metode Penelitian}

Penelitian tindakan kelas ini menggunakan model Kemmis dan Taggart, di mana setiap siklus terdiri dari tiga tahap yaitu perencanaan, pelaksanaan, dan refleksi (Suharsimi Arikunto, 2010: 137). Penelitian tindakan yang dilakukan oleh guru sebagai peneliti dan pengambil kebijakan untuk meningkatkan atau memperbaiki kualitas pembelajaran ke arah pencapaian tujuan pembelajaran yang telah ditetapkan.

\section{Hasil Penelitian}

1. Penyajian Data Hasil Akhir Siklus I dan II

Tabel 1. Rekapitulasi Siklus I dan Siklus II

\begin{tabular}{|c|c|c|c|}
\hline Siklus & Pertemuan & Persentase & Kriteria \\
\hline I & 1 & $65 \%$ & BSH \\
\hline I & 2 & $74 \%$ & BSH \\
\hline II & 1 & $90 \%$ & BSB \\
\hline II & 2 & $96 \%$ & BSB \\
\hline
\end{tabular}

Berdasarkan tabel rekapitulasi data kemampuan bercerita anak di atas menunjukkan adanya peningkatan nilai atau kemampuan yang diperoleh pada setiap tahapannya, mulai dari sebelum tindakan, kemudian dilanjutkan dengan tindakan siklus I dan tindakan siklus II. Hal ini menunjukkan bahwa kegiatan pembelajaran yang diterapkan melalui media Congklak dalam rangka meningkatkan perkembangan kognitif anak meningkat secara signifikan.

\section{Pembahasan}

Penelitian yang telah dilakukan merupakan penelitian tindakan kelas yang terdiri dan 2 Siklus. Setiap Siklus terdiri dan perencanaan, pelaksanaan atau tindakan, observasi, dan refleksi. Hasil yang diperoleh pada siklus ini didapat dari data yang berupa lembar observasi. Dari data lembar observasi tersebut hasilnya akan digunakan untuk mengetahui peningkatan yang terjadi pada anak.

Perkembangan kognitif anak dapat di lihat dari pratindakan berada pada kriteria "belum berkembang". Setelah adanya tindakan pada siklus I yaitu melalui bermain congklak, terjadi peningkatan yaitu hanya ada 4 anak (19\%) anak yang masih dalam kriteria Belum Berkembang (MB). Pada siklus I pertemuan ke 2 persentase perkembangan kognitif anak meningkat 79,76\% dengan kriteria BSB sehingga tindakan dilanjutkan pada siklus II. Adapun hasil tindakan pada siklus II pertemuan ke 2 perkembangan kognitif meningkat menjadi 96\%.

Pada kegiatan ini peneliti dan guru melakukan evaluasi tentang pelaksanaan kegiatan pembelajaran pada siklus II. Refleksi pada siklus II ini guru dan peneliti melakukan penilaian selama proses bermain congklak, masalah yang muncul dan segala yang berkaitan dengan tindakan penelitian ini. Adapun pelaksanaan tindakan siklus II sudah baik. Anak sangat bersemangat dalam pembelajaran karena anak secara aktif terlihat dalam pembelajaran berlangsung dari proses kegiatan awal sampai dengan kegiatan akhir. Kelemahan pada Siklus I dapat teratasi dengan baik pada siklus II. Peningkatan perkembangan kognitif anak terlihat dari tercapainya indikator yang telah ditetapkan. Bermain congklak yang disajikan sudah mampu meningkatkan perkembangan kognitif anak. Pada Siklus II perkembangan kognitif dengan membilang sudah mengalami peningkatan dan telah memenuhi indikator keberhasilan sehingga peneliti dirasa cukup dan dihentikan sampai Siklus II.

Dari hasil penelitian menunjukkan bahwa dengan media yang tepat yaitu congklak dapat membantu meningkatkan perkembangan kognitif anak dalam hal membilang. Pencapaian keberhasilan belajar anak karena keberhasilan guru dalam menggunakan metode, media dan memotivasi anak dalam melakukan tindakan kelas, adapun hasil dari pengamatan tersebut guru 
mampu dan berhasil melakukan tindakan kelas ini dengan baik sehingga pembelajaran dapat tercapai.

Alasan mengapa bermain congklak ini dipilih sebagai media dalam perkembangan kognitif yang dapat meningkatkan kemampuan membilang anak adalah karena media ini sangat sederhana dan mudah digunakan oleh anak bahkan bahannya juga dari lingkungan sekitar anak sehingga itu juga memudahkan bagi anak dalam memainkan media tersebut. Dengan demikian bermain congklak dapat membuat anak merasa rileks dan santai namun tetap belajar, dalam kondisi ini anak akan cepat menyerap pelajaran yang diberikan oleh guru. Maka dari itu media congklak ini sangat diperlukan dan cukup efektif untuk membimlang dan meningkatkan perkembangan kognitif anak usia 5-6 tahun di PAUD Putra Pertiwi Kecamatan Lubuk Sandi Kabupaten Seluma.

\section{Kesimpulan}

Dari hasil penelitian tindakan kelas dan pembahasan seperti telah diuraikan diperoleh kesimpulan terhadap hasil penelitian ini yaitu:

1. Dengan penerapan bermain congklak dapat meningkatkan perkembangan kognitif anak usia 5-6 tahun di Paud Putra Pertiwi Kecamatan Lubuk Sandi Kabupaten Seluma. Peningkatan ini terjadi karena setiap tahap pelaksanaan peretemuan dilakukan perbaikanperbaikan, sehingga anak terbiasa dengan kegiatan pembelajaran dengan menggunakan media congklak.

2. Perkembangan kognitif anak dengan membilang melalui media congklak di Paud Puta Pertiwi Kabupaten Seluma mencapai 96\% dengan kriteria Berkembang Sesuai Harapan.

\section{Daftar Pustaka}

Achroni. 2010. Permainan Modern dan Tradisional AUD. Jakarta: Kencana

Ahmad Susanto, 2011, Perkembangan Anak Usia Dini, Jakarta: Kencana Asri Budiningsih. 2005. Media Pendidikan Anak. Rajawali Pers. Jakarta Daryono. 2013. Psikologi Manusia. Grafindo Media. Yogyakarta

Ernawulan, Mubair Agustin. 2008. Tahap Perkembangan Rentan Usia. Jakarta: Kencana

Fariha. 2011. Tehnik Permainan Tradisional. Rineka Cipta. Jakarta Husdarta, Nurlan. 2010. Rentan Usia Manusia. Jakarta: Kencana
Misyanti.E. 2011. Orientasi Baru Pendidikan Anak Usia Dini Teori dan Aplikasi, Jakarta: Kencana

Moeslichatoen. 2004. Metode Pengembangan Pembelajaran PAUD. Alfabeta. Bandung

Masudah: 2009. Konsep Matematika dalam Pengenalan Bilangan. Remaja Rosdakara. Bandung

Mukhtar Latif. 2013. Permainan bagi Anak Usia Dini. Remaja Rosdakara. Bandung

Mansur. 2011. Konsep Permainan Anak-Anak. Jakarta: Kencana

Mulyasa. 2012. Pedoman Bermaian dan Permaina bagi Anak Usia Dini. Alfabeta. Bandung

Montolalu. 2007. Psikologi Pendidikan Anak Usia Dini. Indeks. Jakarta Nathan. 2010. Bermain Sambil Belajar Di PAUD. Rineka Cipta. Jakarta NMC. 2010. National Council Of Teacher Of Mathematics. Jakarta

Nina Damayanti, 2015. Pengenalan Bilangan Bagi Anak TK. Rineka Cipta. Jakarta

Reza Fauzi. 2010. Mengenal Permainan Tradisional. Remaja Rosdakara. Bandung

Slamet Suyanto, 2015. Pembelajaran Matematika Dasar Bagi Anak Kesulitan Belajar. Alfabeta. Bandung

Sri Ningsih. 2008. Belajar dan Pembelajaran AUD. Rineka Cipta. Jakarta Siti Partini. 2003. Psikologi Perkembangan Anak. Rineka Cipta. Jakarta

Suharsimi Arikunto, 2010. Penelitian Kualitatif, Kuantitatif, R\&D dan PTK bagi Pemula. Bandung. Alfabeta

Soemiarti, Patmonodewo. 2003. Psikologi Anak Usia Dini. Citra Publishing. Jakarta

Suyanto. 2005. Pembelajaran Logic Matematic Permulaan. Remaja Rosdakara. Bandung

Tombokan Runtukahu, 2014. Prinsip Membilang Bagi Anak Usia Dini. Alfabeta. Bandung

Undang-Undang Republik Indonesia No. 20 Tahun 2003 tentang Sistem Pendidikan Nasional Bab 1, Pasal 1, Butir 14

Partini, 2010, Pengantar Pendidikan Anak Usia Dini, Grafindo Litera Media: Yogyakarta

Permendikbud No. 137 Tahun 2014. Standar Nasional Pendidikan Anak Usia Dini. Jakarta

Yazid Busthomi. 2012: Konsep Permainan AUD. Remaja Rosdakara. Bandung

Yuliani. 2016. Pola dan Tolak Ukur Kemampuan Dalam Diri. Jakarta: Kencana 